Article

\section{Influence of environmental factors on the interannual variability of macrozoobenthos of the floodplain lakes}

\author{
Alexander A. Prokin ${ }^{1,2 *}{ }^{\circledR}$, Dmitry G. Seleznev ${ }^{1}$, \\ Alexander I. Tsvetkov ${ }^{1}$
}

\begin{abstract}
1'.D. Papanin Institute for Biology of Inland Waters, Russian Academy of Sciences, Borok 109, Nekouz District, Yaroslavl Region, 152742 Russia

${ }^{2}$ Voronezh State University, Universitetskaya square 1, Voronezh, 394018 Russia

*prokina@mail.ru
\end{abstract}

Received: 06.03.2021

Revised: 03.04.2021

Accepted: 14.04 .2021

Published online: 20.05.2021

DOI: $10.23859 /$ estr-210306

UDC 574.587(285.2):592(470)

Translated by D.M. Martynova
Abstract. The changes in depth, temperature, water conductivity, and dissolved oxygen concentration in six floodplain lakes are described in regard to the dynamics of spring flooding and overgrowth by macrophytes. The influence of these factors on the composition and structure of macrozoobenthos communities is analyzed. The observed number of species refers to $60 \%$ of the theoretically predicted, which allows us to assume that the fauna has been identified sufficiently enough to analyze the interannual changes. Six families of invertebrates, which form together $55 \%$ of the fauna, are the richest in species number. The distribution of species by families also confirms enough data on the fauna representing in the obtained and analyzed samples. Abundance of only two species depend significantly on environmental characteristics; the taxonomic and trophic groups exhibit more links to the environment. Totally, 45 mutually associated species $(43.7 \%$ of the total list) have been identified; they form 8 groups that are characterized by connectivity of the species composition ranging as $0.28-1.0$ link/species, the average connectivity strength of $0.67-$ 0.80 , and the strength of species connectivity of $0.38-0.84$ (the last index is proposed for the first time). Groups of mutually associated species may be defined as "faunistic cores of communities" confined to certain lakes and/or years of study. According to the redundancy analysis with multidimensional scaling ordination, the environmental factors affect the quantitative characteristics and overall taxonomic richness of communities. The indices, describing the structure of communities, do not depend on the analyzed factors, which is also confirmed by correlation analysis.

Keywords: macroinvertebrates, small water bodies, community structure, environmental characteristics, connectivity of species composition. 


\section{Introduction}

Currently, the degradation of floodplain ecosystems is observed on a global scale (Erwin, 2009; Tockner and Stanford, 2002; Tockner et al., 2000); therefore, the studies of such pristine water bodies is important for their conservation and restoration.

The authors have performed the studies of benthic and phytophilic macroinvertebrates in a number of floodplain lakes of the Khopyor Nature Reserve (Russia). The territory of the reserve covers the valley of the unregulated Khopyor River, more than 400 water bodies are characterized as pristine. The Russian desman Desmana moschata (Linnaeus, 1758) inhabits some of these lakes; this species of aquatic insectivores is included into the Red Data Books of the IUCN, Russia, and Voronezh Region.

Our previous publications provide data on the qualitative and quantitative composition, seasonal dynamics of macrozoobenthos, describe the role of spring floods in the formation of benthic communities, confirm the importance of drying out or a sharp decline water level as a trigger for ecosystem restructuring in small lakes (Prokin, 2014; Prokin and Reshetnikov, 2013; Prokin and Seleznev, 2018, etc.). During the period of normalization of the floodwater regime after a long-lasting dry period, a homogenization (term after: Thomas et al., 2007) of the species composition was observed, accompanied by an increase in taxonomic and trophic diversity, as well as the alignment of the saprobiological and dominant-informational structure of communities (Prokin and Seleznev, 2021, in press).

However, our earlier data, describing the dynamics of the total species richness, quantitative characteristics, and some structural indicators of communities in different years, do not include an analysis of the influence of a number of key factors on particular species, their taxonomic and trophic groups.

The study aims to assess the variability of macrozoobenthos communities depending on the particular year (i.e. environmental peculiarities) and on the specific characteristics of lakes and biotopes, as well as to analyze the relationship of taxonomic composition with key environmental factors (depth, water temperature, electrical conductivity, duration of standing of flood waters in the lake, and relative area overgrown by macrophytes).

\section{Materials and methods}

The studies were carried out in 2011-2013 on six floodplain lakes belonging to the catchment area of the Khoper River, on the territory of the Khopyor Nature Reserve: the Lake Maloe Goloe (M. Go-

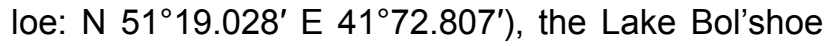
Goloe (B. Goloe: N 51 $20.373^{\prime}$ E 41 411.859'), the Lake Ul'yanovskoe (N 51 $22.243^{\prime}$ E $41^{\circ} 71.364^{\prime}$ ), the Lake Bol'shoe Shchuryach'e (B. Shchuryach'e: N 51⒉ $21.863^{\prime}$ E $\left.41^{\circ} 70.623^{\prime}\right)$, the Lake Bol'shoe
Podpesochnoe (B. Podpesochnoe: N 51 ${ }^{\circ} 22.853^{\prime}$ E $\left.41^{\circ} 70.255^{\prime}\right)$, and the Lake Krutoberezhnoe

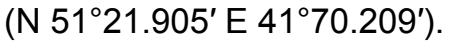

Macrozoobenthos was sampled by a Petersen bottom grab with a capture area of $0.025 \mathrm{~m}^{2}$ (2011) and a DAK-100 box grab with a capture area of $0.01 \mathrm{~m}^{2}(2012-2013)$. Two replicates were taken in three biotopes of each lake: (1) the deepest area, usually outside the thickets of macrophytes ("profundal"), (2) littoral in the belt of plants with floating leaves (littoral), and (3) the belt of helophytes (water edge zone).

The sampled material was immediately fixed in $75 \%$ ethanol; the species were identified in laboratory. A total of 51 samples were taken and processed. The list of the taxonomic keys for invertebrate identification has been presented earlier (Prokin and Reshetnikov, 2013).

Information on the trophic specialization of organisms is obtained from the summary by A.V. Monakov (Monakov, 2003); the classification of trophic groups and guilds is given according to the summary by A.E. Silina and A.A. Prokin (Silina and Prokin, 2008).

Physical and chemical characteristics of water were measured with a multiparameter hand-held probe "YSI 85" (YSI Incorporated, USA, 2012) in the near-bottom layer. The water temperature $\left(T w,{ }^{\circ} \mathrm{C}\right)$, electrical conductivity $(E C, \mu S / \mathrm{cm})$, reduced to a temperature of $25^{\circ} \mathrm{C}$, and the concentration of dissolved oxygen $\left(\mathrm{O}_{2}, \mathrm{mg} / \mathrm{L}\right)$ were analyzed.

The Species Sampling Relationship (SSR) model was used to assess the completeness of the invertebrate fauna in the samples from the studied biotopes (Schoener, 1976). Empirical data were used to simulate the statistical distribution of the number of species by the Monte Carlo method with 50000 permutations for the aggregated data and 10000 permutations for particular years. Accumulation curves were approximated by a rational function of the first order

$$
f(x)=\frac{a+b \cdot x}{1+c \cdot x},
$$

with a finite limit (Ratkowsky, 1990). The parameters $(a, b, c)$ of the rational function were selected by the nonlinear least squares regression.

The population density index (IP) was used to analyze the dependence of the abundance of species and groups on the physicochemical characteristics of water:

$$
\mathrm{IP}=\sqrt{n \cdot b},
$$

where $n$ is the species abundance, ind. $/ \mathrm{m}^{2}, b$, the species biomass, $\mathrm{g} / \mathrm{m}^{2}$ (Arabina et al., 1988).

The analysis was carried out using a permutation linear model, which was proved to work well enough when processing small samples (Kabacoff, 2011). The significance of the differences in mean values depending on the year, lake, and biotope was assessed 
by the analysis of variance using a randomization test. The analysis included species and groups that were present in at least five samples. Post hoc analysis was performed using Tukey's HSD test.

The hypergeometric distribution was applied to determine the mutually associated species on the basis of qualitative dataset. This method allows to assess similar or greater (lesser) probability of finding of certain species in sample that already contains another species (Griffith et al., 2016). The level of significance was set as 0.05 . The vertices in the graph of mutually associated species were grouped by the multi-level modularity optimization algorithm (Blondel et al., 2008).

The general connectivity of the group was assessed by two characteristics: (1) the proportion of realized connections from their maximum possible number in the group (the connectivity of the species composition) and (2) the average strength of the realized connections in the group. The connectivity was calculated as:

$$
C n=\frac{2 k}{n \cdot(n-1)},
$$

where $k$ is the number of realized connections in the group, $n$ is the number of species in the group.

The connection strength was calculated by the Fuger's index (Sheth et al., 2021):

$$
C f=\frac{2 N_{12}}{N_{1}+N_{2}},
$$

where $N_{1}$ and $N_{2}$ are the number of samples containing the first and second species; $N_{12}$ is the number of samples containing both species together.

We propose to term the integral characteristic of the two above-mentioned parameters as the strength of connectivity of the species composition. Since both of its components are normalized to the range $[0,1]$, their average is calculated using the rule for finding the average percentages:

$$
C s=\frac{2 \cdot(C n+C f)}{2 \cdot k+n \cdot(n-1)}
$$

When studying the structure of macrozoobenthos, a number of characteristics calculated on average for the lake per year were analyzed: species richness ( $n$, number of species), Shannon's diversity index $(H$, bits/ind.) (Odum, 1969), Simpson's dominance index in terms of abundance $\left(C_{N}\right)$ (Simpson, 1949), and von Foerster parameter of organization of the system $(R)$ (von Foerster, 2003). The relationship between the indices of community structure $\left(H, C_{N}\right.$, and $\left.R\right)$ and the physicochemical characteristics of water was checked using Kendall's rank correlation (Kendall, 1938).

Ordination diagrams of quantitative and structural characteristics of communities were constructed using the method of redundancy analysis (RDA).
The calculations were performed in the $\mathrm{R} 3.6$ statistical analysis environment using the igraph, ImPerm, and vegan packages. The primary data and functions for calculating and visualizing of mutually associated species groups in the $R$ language are available at: https://doi.org/10.23859/estr-210306.

\section{Results}

In 2012, the water temperature of the studied lakes was lower than in 2011; the year of 2011 was one of the warmest years for the period of observations. The average seasonal temperature anomaly over the territory of Russia in 2011 was $+1.4^{\circ} \mathrm{C}^{1}$. In 2013 , the water temperature $(T w)$ in most lakes was even lower than in the same period of 2012. The only exceptions were the lakes M. Goloe and B. Goloe, where the temperature in 2013 was higher by $0.7^{\circ} \mathrm{C}$ than in warm 2011. Apparently, this could be due to a change in the lake's groundwater supply regime (Prokin, 2014; Prokin and Seleznev, 2018). During the study period, the temperature of the bottom water layer of all lakes regularly increased from the "profundal" to the shoreline zone (Appendix: khoper_env by_biotope.csv).

The oxygen concentration was minimal in the "profundal" of the Lake M. Goloe in 2011 and in the littoral and "profundal" of the Lake B. Goloe in 2012. In other lakes, the minimums were observed in 2012 and 2013 in the "profundal". In the coastal zone, the oxygen concentration varied greatly: from 2012 to 2013 , it increased in the Lake Ul'yanovskoe, the Lake B. Podpesochnoe, the Lake Krutoberezhnoe, but decreased in the Lake M. Goloe and the Lake $B$. Shchuryach'e. In the littoral, the values were characterized by even larger variability, increasing in all lakes from 2012 to 2013 (Appendix: khoper_env_by_ biotope.csv).

The Lake M. Goloe was characterized by the minimum electrical conductivity in all years and in all biotopes; the Lake B. Podpesochnoe, by maximum values in 2011. In the other lakes, this parameter varied within the average values, reaching maximum in 2011 and in the "profundal" (in all years), as well as decreasing in 2013 compared to 2012 (Appendix: khoper_env_by_biotope.csv).

The approximation limit is 171 species for the accumulation curve in the SSR model built for all species found (103 species). This limit is close to the recorded number of species (176) taking into account phytophilic fauna (Prokin, 2014; Prokin and Reshetnikov, 2013). The species found in the macrozoobenthos make up $60 \%$ of the theoretically predicted amount (Fig. 1).

\footnotetext{
${ }^{1}$ Report on the peculiarities of the climate in the territory of the Russian Federation in 2011. URL: http://meteoinfo.ru/media/ climate/rus-clim-2011.pdf
} 
A

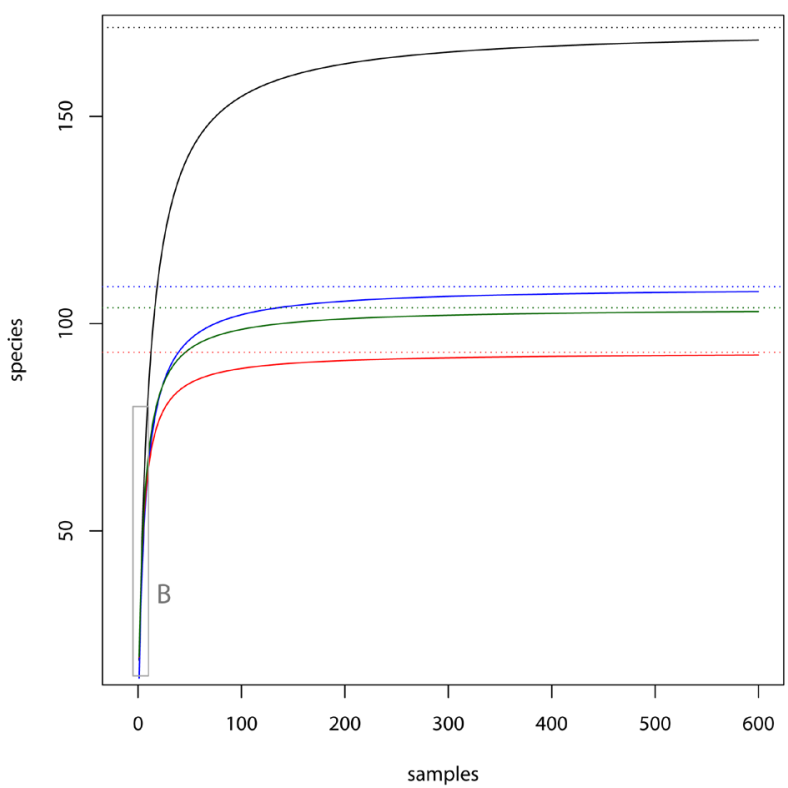

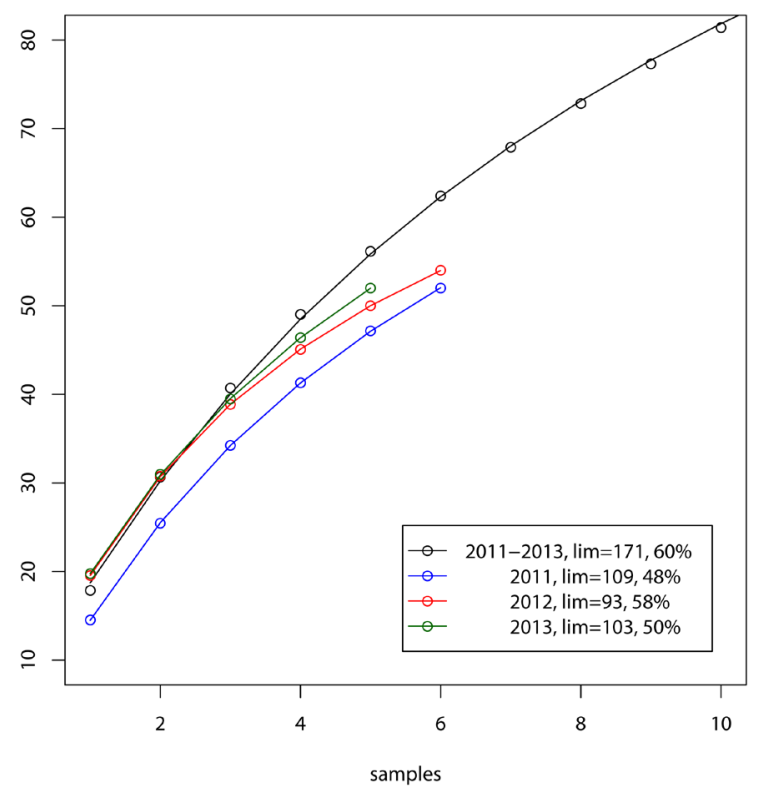

Fig. 1. Accumulation curves of species: A - fitted approximating curves (horizontal lines show their limits); B - empirical data (markers) and approximating curves for 10 samples; lim - the approximation limit for the sample effort $x \rightarrow \infty ; \%$ - the proportion of the number of detected species from the approximation limit number.

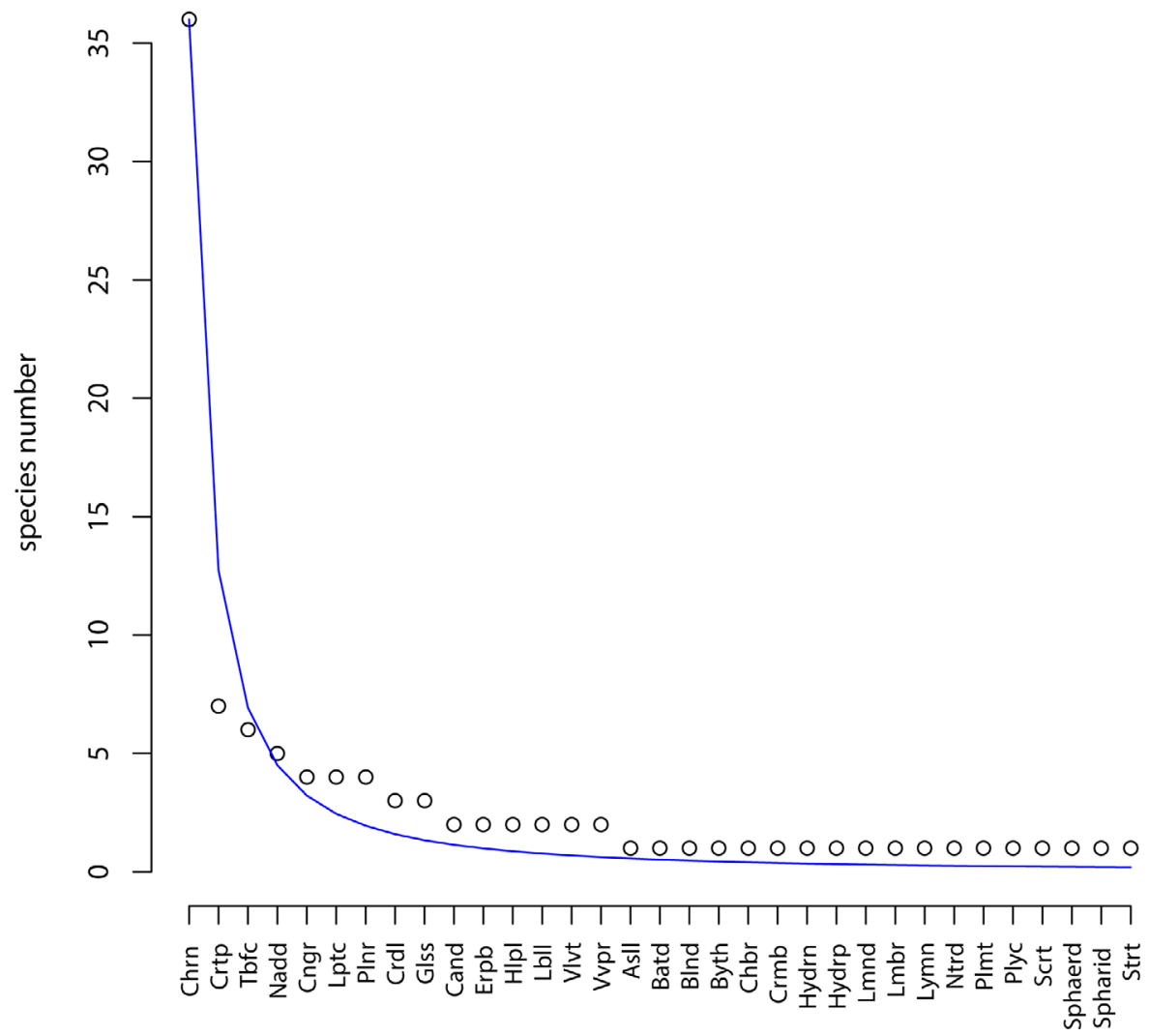

families

Fig. 2. Macrozoobenthos species by families in the samples obtained in 2011-2013. Chrn - Chironomidae, Crtp - Ceratopogonidae, TbfcTubificidae, Nadd - Naididae, Cngr - Coenagrionidae, Lptc - Leptoceridae, PInr - Planorbidae, Crdl - Corduliidae, Glss - Glossiphonidae, Cand - Caenidae, Erpb - Erpobdellidae, Hlpl - Haliplidae, Lbll - Libellulidae, Vlvt - Valvatidae, Vvpr - Viviparidae, Asll - Asellidae, Batd Baetidae, Blnd - Bulinidae, Byth - Bythiniidae, Chbr - Chaoboridae, Crmb - Crambidae, Hydrn - Hydraenidae, Hydrp - Hydroptilidae, Lmnd - Limoniidae, Lmbr - Lumbricidae, Lymn - Lymnaeidae, Ntrd - Noteridae, PImt - Plumatellidae, Plyc - Polycentropodidae, Scrt Scirtidae, Sprd - Sphaeriidae, Strt - Stratiomyidae. 
Approximation of empirical data by a rational function for each year separately distinguishes 2012 as the poorest year in potential species richness, but the species have been represented most fully in the samples (Fig. 1). The years of 2011 and 2013 are potentially richer by species number, but the degree of detection of fauna is lower in these years. Analysis of the accumulation curves allows us to assume that the fauna has been identified sufficiently enough to analyze the interannual changes.

The general taxonomic diversity revealed over the entire study period (Fig. 2) is in good agreement with the Willis law formulated for families: the ratio of species frequency of occurrence by families is described by a hyperbolic distribution (Pozdnyakov, 2005) with $a=0.5$, which confirms our assumption of sufficient faunistic data on the macrozoobenthos of lakes, based on the analysis of accumulation curves (see above).

The dependence of the density indices of species and groups by biotopes in all samples on the environmental characteristics is presented in Table 1; electrical conductivity is excluded from this table, since no reliable dependence has been found. Only two species depend significantly on the environmental characteristics; this is due a relatively small number of samples, where these species have been found. Taxonomic and trophic groups, which combine certain species, are represented more widely in this regard.

Abundance and biomass of Chaoborus flavicans (Meigen, 1830) increased accordingly to the lake depth and decreased as the water temperature and dissolved oxygen concentration increased (Table 3). Chironomid Glyptotendipes cauliginellus (Kieffer, 1913), Odonata, Corduliidae, and Ceratopogonidae preferred warm waters. Glossiphonidae responded significantly to the oxygen concentration only (Table 1).

The abundance and biomass of detritivores and obligate predators decreased with depth, but increased along the water temperature increase; the abundance and biomass of detritivores and sestonodetrivores depended positively on the concentration of dissolved oxygen (Table 1).

The species abundance and biomass did not depend neither on the sampling year, nor on the lake type and biotope. Taxonomic and trophic groups in certain lakes did not have any preferences either; however, preferences for a certain type of biotope were found for the order Diptera and the trophic group of detritivores. However, the significance levels of these dependencies ( 0.05 and 0.038 , respectively) were close to or equal to the critical value (0.05). The dependency of abundance and biomass on the biotope type should be interpreted as ambiguous, and thus they were not discussed, considering the small amount of primary data and application of permutation analysis of variance. The latter, when applied repetitively, might result as overestimated significance level (above the critical value). The dependence of abundance and biomass of Naididae on the sampling year

Table 1. Dependence of the density indices of species, trophic and taxonomic groups on depth $(D)$, water temperature (Tw), and concentration of dissolved oxygen $\left(\mathrm{O}_{2}\right) ; b$ - regression coefficient, $p$ - significance level.

\begin{tabular}{|c|c|c|c|c|c|c|}
\hline \multirow{2}{*}{ Species / group } & \multicolumn{2}{|c|}{$D$} & \multicolumn{2}{|c|}{$T w$} & \multicolumn{2}{|c|}{$\mathrm{O}_{2}$} \\
\hline & $b$ & $p$ & $b$ & $p$ & $b$ & $p$ \\
\hline $\begin{array}{l}\text { Chaoborus flavicans } \\
\text { (Meigen, 1830) }\end{array}$ & 373.44 & 0.031 & -117.79 & 0.010 & -164.46 & 0.040 \\
\hline $\begin{array}{l}\text { Glyptotendipes cauliginellus } \\
\text { (Kieffer, 1913) }\end{array}$ & - & - & 1103.99 & 0.023 & - & - \\
\hline Chironomidae & -1116.87 & 0.015 & 282.84 & 0.006 & 544.21 & 0.002 \\
\hline Ceratopogonidae & - & - & 15.08 & 0.033 & - & - \\
\hline Glossiphonidae & - & - & - & - & 86.44 & 0.035 \\
\hline Odonata & - & - & 67.71 & 0.035 & - & - \\
\hline Corduliidae & - & - & 36.16 & 0.008 & - & - \\
\hline Detritivores & -977.23 & 0.008 & 248.14 & 0.004 & 346.02 & 0.011 \\
\hline Sestono-detrivores & - & - & - & - & 251.02 & 0.005 \\
\hline Obligate predators & -212.1 & 0.039 & 47.86 & 0.039 & - & - \\
\hline
\end{tabular}


(0.041) might also be considered as doubtful. Several taxa of the family and order rank (Ceratopogonidae, Chironomidae, Corduliidae, Diptera, and Odonata), as well as trophic groups of sestono-detrivores and obligate predators, demonstrated a significant relationship with the sampling year (Table 2). In all cases, the dependence of the studied parameters on the sampling year was preconditioned by the minimum values of the group abundance/biomass in 2011, the maximum, in 2012, and intermediate, in 2013 (Table 2).

A total of 45 mutually associated species $(43.7 \%$ of the total list) were identified, which formed 8 groups (Fig. 3). Two of them were represented by pairs of species not related to others: I: Planorbarius sp. Glyptotendipes glaucus (Meigen, 1818), recorded together in the Lake B. Podpesochnoe and the Lake M. Goloe in 2012 and in the Lake B. Podpesochnoe in 2013; VI: Hemiclepsis marginata (O.F. Müller, 1774) Zavreliella marmorata (van der Wulp, 1859), the Lake B. Podpesochnoe and the Lake Krutoberezhnoe in 2013.

Other groups formed two clusters $(\mathrm{II}+\mathrm{III+IV+V}$ and $\mathrm{VII}+\mathrm{VIII})$, which are combined due to single connections of pairs of species from neighboring groups (Fig. 3). Species from the first cluster were predominantly found together in 2012-2013, from the second, in 2011.

The identified groups included the species most often found together: II - in the Lake M. Goloe and the Lake B. Shchuryach'e in 2013; III - in different lakes in 2012-2013, in communities dominated by Chironomus cingulatus Meigen, 1830 and Glyptotendipes cauliginellus; IV - in the Lake M. Goloe and the Lake B. Shchuryach'e in 2012; V - in the Lake B. Goloe and the Lake M. Goloe in 2012 (mainly bottom-phytophilic species, the linking species was Bithynia tentaculata (Linnaeus, 1758)); VII - the Lake M. Goloe and the Lake B. Podpesochnoe in 2011 (the linking species was Coenagrion hastulatum
Charpentier, 1825); VIII - the Lake Krutoberezhnoe and the Lake B. Podpesochnoe in 2011.

In most cases, one species was associated with one species (10 species, $22.2 \%)$, two species (17, $37.8 \%$ ), or three species $(11,24.4 \%)$. Association with larger number of species was less common: five species $(4,8.9 \%)$, four, six, and seven (1, 2.2\% each). The species with the maximum number of connections can be called linking, since they largely determined the structure of groups (in this case, Chironomus cingulatus in group III and Bithynia tentaculata in group V).

Groups I and VI, comprising two species each, exhibited the maximum strength of species composition connectivity (Table 3 ). Since this was achieved by the only possible relationship, such groups could be excluded from the comparison. Groups II, V, and VIII were characterized by high strength of connectivity, groups IV and VII, by low.

Correlation analysis of the relationship between the Shannon, von Foerster, and Simpson indices did not reveal significant relationships with the physicochemical characteristics of water and with lake biotopes over the years (the Kendall correlation ranged from -0.15 to 0.39 ).

Multidimensional ordination evidenced that all environmental factors contributed mainly to the horizontal component of RDA1 $(69 \%$ variability versus $22 \%$ ), along which they were divided into two oppositely directed groups: the first group was the flood period and water temperature; the second group comprised the electrical conductivity, the concentration of dissolved oxygen, and overgrowth by macrophytes. According to the generalized quantitative and structural characteristics of lake communities by sampling years (black markers) in the space of environmental factors, the communities of the Lake B. Goloe and the Lake Krutoberezhnoe in 2011 were distinguished as the least aligned and independent of factors, the communities of the

Table 2. Average values of species density indices of taxonomic and trophic groups; $p$ - the significance level of the permutation analysis of variance; the letters A, B, AB denote the differences according to the Tukey's HSD test.

\begin{tabular}{ccccc}
\hline Group & $p$ & & Year & \\
& & 2011 & 2012 & 2013 \\
\hline Ceratopogonidae & 0.016 & $0.56^{\mathrm{B}}$ & $6.44^{\mathrm{A}}$ & $2.92^{\mathrm{AB}}$ \\
Chironomidae & 0.003 & $10.34^{\mathrm{B}}$ & $158.92^{\mathrm{A}}$ & $98.84^{\mathrm{AB}}$ \\
Corduliidae & 0.005 & $4.97^{\mathrm{B}}$ & $59.49^{\mathrm{A}}$ & $10.08^{\mathrm{B}}$ \\
Diptera & $<<0.001$ & $22.03^{\mathrm{B}}$ & $148.22^{\mathrm{A}}$ & $113.46^{\mathrm{A}}$ \\
Odonata & $<<0.001$ & $3.58^{\mathrm{B}}$ & $69.30^{\mathrm{A}}$ & $20.27^{\mathrm{B}}$ \\
Sestono-detrivores & 0.02 & $11.23^{\mathrm{B}}$ & $93.22^{\mathrm{A}}$ & $44.61^{\mathrm{AB}}$ \\
Obligate predators & $<0.001$ & $5.59^{\mathrm{B}}$ & $69.63^{\mathrm{A}}$ & $17.35^{\mathrm{B}}$ \\
\hline
\end{tabular}




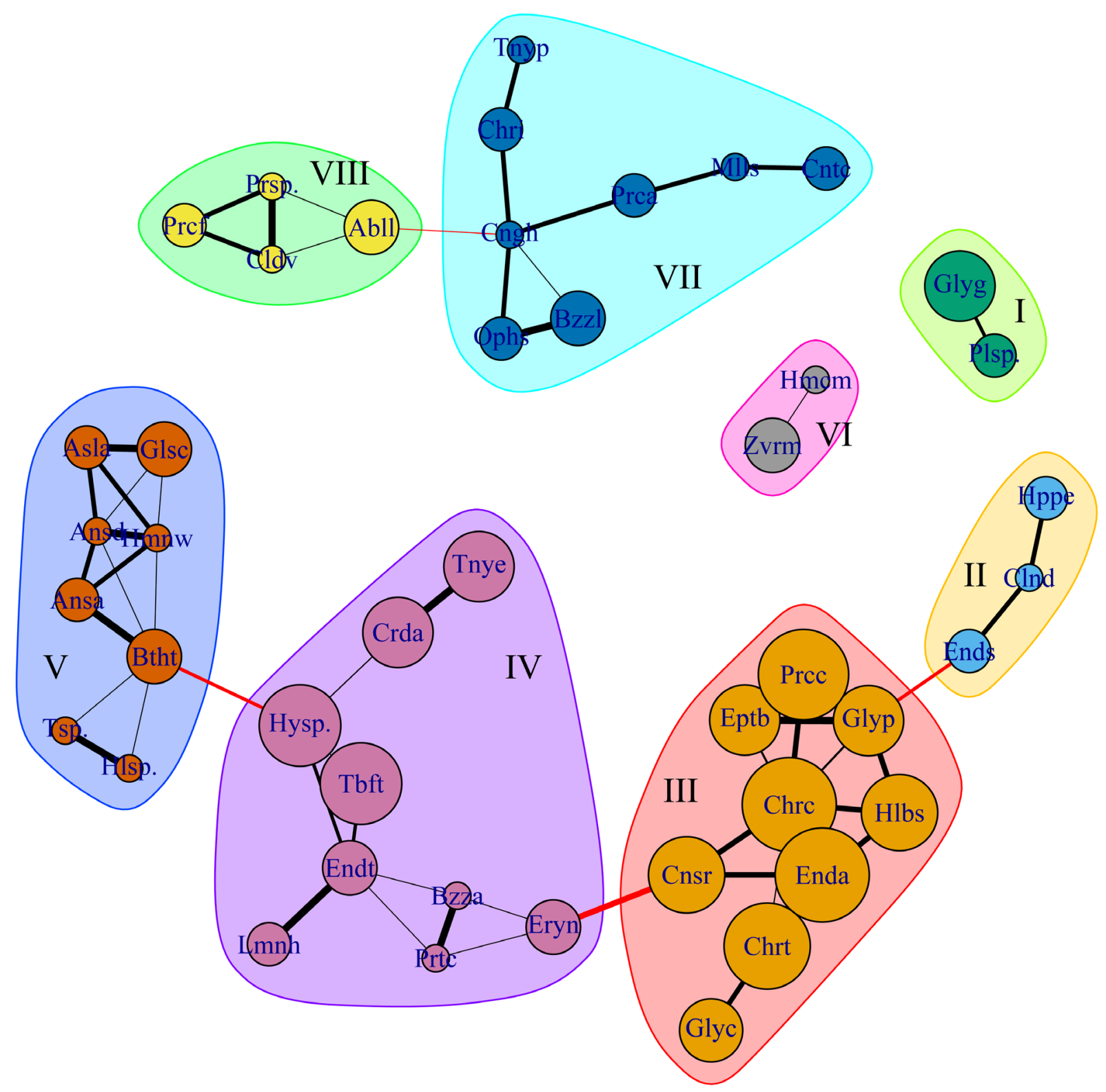

Fig. 3. Graph of mutual connectivity of macrozoobenthos species. The marker size is logarithmically proportional to the frequency of occurrence of certain species in samples; the thickness of the edge reflects the strength of the connection between the species and is inversely proportional to the level of significance of the connection. Abll - Ablabesmyia longistyla Fittkau, 1962, Ansa - Anisus albus (O.F. Müller, 1774), Ansd - A. dispar (Westerlund, 1771), Asla - Asellus aquaticus Linnaeus, 1758, Bzza - Bezzia annulipes (Meigen, 1830), Bzzl - B. leucogaster (Zetterstedt, 1850), Btht - Bithynia tentaculata (Linnaeus, 1758), Cnsr - Caenis robusta Eaton, 1884, Chrc Chironomus cingulatus Meigen, 1830, Chri - Ch. improvisus Shobanov, 2004, Chrt - Ch. tentans Fabricius, 1805, Cldv - Cladopelma viridula (Linnaeus, 1767), Clnd - Cloeon gr. dipterum, Cngh - Coenagrion hastulatum Charpentier, 1825, Cntc - Contectiana contecta (Millet, 1813), Crda - Cordulia aenea (Linnaeus, 1758), Enda - Endochironomus albipennis (Meigen, 1830), Ends - E. stackelbergi Goetghebuer, 1935, Endt - E. tendens Fabricius, 1775), Eptb - Epitheca bimaculata (Charpentier, 1825), Eryn - Erythromma najas (Hansemann, 1823), Glsc - Glossiphonia complanata (Linnaeus, 1758), Glyc - Glyptotendipes cauliginellus (Kieffer, 1913), Glyg - G. glaucus Meigen, 1818, Glyp - G. paripes (Edwards, 1929), Hmcm - Hemiclepsis marginata (O.F. Müller, 1774), Hmnw - Haemonais waldvogeli Bretscher, 1900, Hlsp - Haliplus sp., Hlbs - Helobdella stagnalis (Linnaeus, 1758), Hppe - Hippeutis euphaea (Bourguignat, 1864), Hysp - Hydracarina spp., Lmnh - Limnodrilus hoffmeisteri Claparede, 1862, Mlls - Mallochohelea setigera (Loew, 1864), Ophs - Ophidonais serpentina (O.F. Müller, 1774), Prca - Parachironomus arcuatus (Goetghebuer, 1919), Prtc - Paratanytarsus confusus Palmen, 1960, Prsp - Paratanytarsus sp., Plsp - Planorbarius sp., Prcc - Procladius choreus (Meigen, 1804), Prcf - P. ferrugineus (Kieffer, 1918), Tnye - Tanytarsus excavatus Edwards, 1929, Tnyp - T. pallidicornis (Walker, 1856), Tsp - Tanytarsus sp., Tbft - Tubifex tubifex (O.F. Müller, 1774), Zvrm - Zavreliella marmorata (van der Wulp, 1859). 
Table 3. Characteristics of the structure of groups of mutually associated species (based on Fig. 3).

\begin{tabular}{cccccccccc}
\hline Parameter & \multicolumn{7}{c}{ Groups of species } \\
& I & II & III & IV & V & VI & VII & VIII \\
\hline Number of species & 2 & 3 & 9 & 9 & 8 & 2 & 8 & 4 \\
$\quad$ Number of connections & 1 & 2 & 13 & 10 & 14 & 1 & 8 & 5 \\
$\begin{array}{c}\text { Potential number of connections } \\
\quad \begin{array}{c}\text { Connectivity of species } \\
\quad \text { composition }\end{array}\end{array}$ & 1 & 3 & 36 & 36 & 28 & 1 & 28 & 6 \\
$\begin{array}{c}\text { Average strength } \\
\text { of the connection }\end{array}$ & 0.67 & 0.8 & 0.78 & 0.74 & 0.78 & 0.67 & 0.79 & 0.79 \\
$\begin{array}{c}\text { Strength of the species } \\
\text { composition connectivity }\end{array}$ & 0.84 & 0.72 & 0.47 & 0.38 & 0.59 & 0.84 & 0.4 & 0.81 \\
\hline
\end{tabular}

remaining lakes in 2011, as the least abundant, and the community of the Lake M. Goloe in 2012, as the most abundant and rich in species. This result confirmed good consistency of the ordination diagram with the dataset.

Quantitative characteristics (total abundance, abundance of the dominant) and species richness of communities were associated with the flood period, proven earlier by other methods (Prokin and Seleznev, 2018), as well as with water temperature (Fig. 4). At the same time, the structural characteristics of communities $\left(H, C_{N}\right.$, and $\left.R\right)$ located orthogonal to the horizontal component of RDA1, i.e., they do not show any connection with the studied environmental factors (Fig. 4).

\section{Discussion}

According to V.V. Davydenko and V.I. Biryukov (2014), the large spring floods occurred fivefold more frequently from 1935 to 1973 comparing to the period of 1974-2012. The flood in 2012 finished dry period started as early as in 1972 . This was preceded by the minimum groundwater level in 2011 (in $75 \%$ of observation sites); a critical (absolute minimum) level was registered in $61 \%$ of the lakes in the reserve, or the water level was close critical (Davydenko and Biryukov, 2014). Similar data were presented by E.V. Gurevich and M.L. Markov (2017) for the water bodies of the Lipetsk Region; these authors associated the minimum groundwater levels with a decrease in winter and spring precipitation. In general, the hydrological regime of the floodplain water bodies of the Khopyor River was absolutely determined by the maximum level of spring floods and the duration of this period; during the summer-autumn low water period it also depended on the amount of precipitation and air humidity (Egunova and Kharchenko, 2020).
During the study period, the area of the lakes varied from 0.003 to $0.13 \mathrm{~km}^{2}$, the maximum depth was $5.9 \mathrm{~m}$. The absence of spring flood was observed in the Lake Krutoberezhnoe in 2011, in the lakes Ul'yanovskoe, B. Shchuryach'e, and B. Podpesochnoe, from 2006 to 2012. As a result of the powerful flood in 2012, the water surface area of the studied water bodies increased by $24-60 \%$, and the maximum absolute increase of water level was $5 \mathrm{~m}$ comparing to that in March, which exceeded the average long-term values by $1.5 \mathrm{~m}$. In 2013, no flood was registered in the Lake Ul'yanovskoe, but the flood waters stood in the other lakes for more than 2 months. At the same time, the area of lakes decreased by $5-25 \%$, except for the Lake Krutoberezhnoe, which water area has not changed. Regard must be paid to the Lake B. Goloe and the Lake M. Goloe, the first one was connected with the Khopyor river through a natural channel, the second was connected to the first lake. During the period of study, these lakes were flooded annually, their area was $100 \%$ of the mean annual, and the flood period increased from 25 to 45 days (Prokin, 2014; Prokin and Seleznev, 2018).

The increase in the area of lakes in 2012 contributed to a decrease in the degree of their overgrowth with macrophytes by 10-60\%; except the Lake Krutoberezhnoe, where it has increased by $30 \%$ due to the growth of the fern Salvinia natans (L.)All. The minimum degree of overgrowth (20-30\%) was registered in the Lake $B$. Podpesochnoe. In 2013, the area of overgrowth of the lakes M. Goloe, B. Goloe, and B. Podpesochnoe did not change; in the Lake Ul'yanovskoe, significantly increased; in the Lake B. Shchuryach'e, slightly decreased; and decreased drastically in the Lake Krutoberezhnoe (Prokin, 2014; Prokin and Seleznev, 2018). 


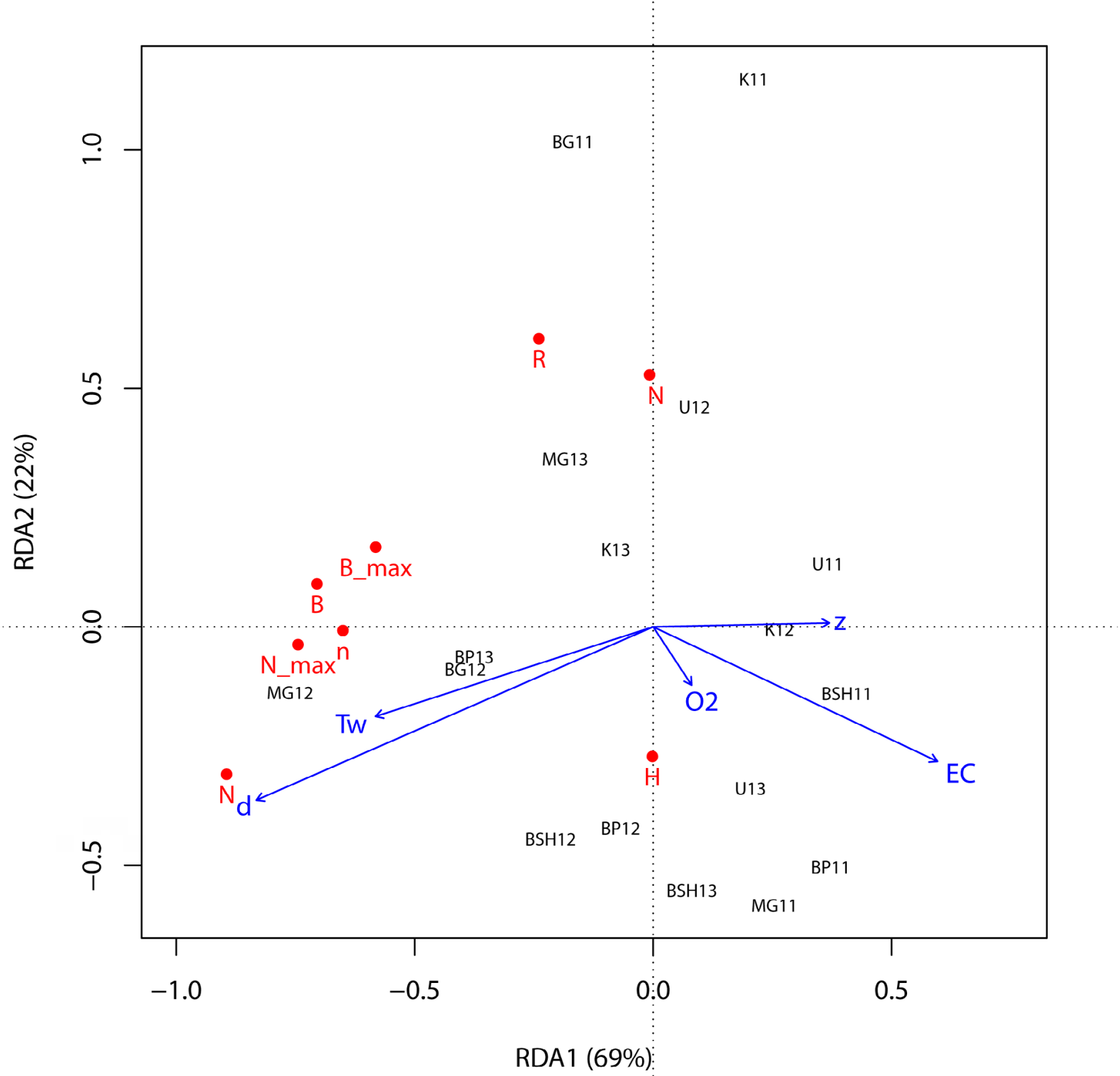

Fig. 4. Ordination diagram of the relationship of environmental factors with the giuantitative and structural characteristics of communities. The environmental factors are marked in blue: $d$ - duration of standing of flood waters, Tw - water temperature, EC - electrical conductivity, $\mathrm{O}_{2}$ - concentration of dissolved oxygen, $\mathrm{z}$ - proportion of overgrowth with macrophytes (\% of the lake area). The characteristics of communities are given in red: $\mathrm{n}$ - number of species, $\mathrm{N}$ - the total abundance, $\mathrm{N}$ max - abundance of the dominant species, $\mathrm{B}-$ total biomass, B_max - maximum biomass of the species (dominant); $\mathrm{H}$ - Shannon index, $\mathrm{CN}$ - Simpson dominance index, $\mathrm{R}-$ von Foerster index. The generalized characteristics of lake communities by years are shown in black: MG - the Lake M. Goloe, BG - the Lake B. Goloe, $\mathrm{U}$ - the Lake Ul'yanovskoe, K - the Lake Krutoberezhnoe, BP - the Lake B. Podpesochnoe, BSH - the Lake B. Shchuryach'e; 11 - 2011, $12-2012,13-2013$.

Low electrical conductivity of the water in the Lake M. Goloe was probably due to the inflow of groundwater from a nearby forest. In addition, it could be associated with a significant overgrowth of the lake with macrophytes (80\%) and saturation of water with dissolved oxygen. The maximum electrical conductivity in the Lake B. Podpesochnoe in 2011 could be explained by the absence of connection with the river for five years and by the maximum depth of the lake $(5.9 \mathrm{~m}$, with an average of $2.3 \mathrm{~m})$ with a minimum overgrowth $(30 \%)$. Probably, ions coming from the bottom of the basin were less accumulated here by macrophytes due to relatively large depths.
The curves of species accumulation in the SSR model did not coincide with the data obtained for 628 samples of macrozoobenthos of the rivers of the Samara Region, where asymptotic species saturation was not found (Shitikov et al., 2012). Probably, the fauna of the studied lakes were less diverse comparing with that in the rivers; therefore, sampling by a bottom grab here resulted in more reliable data compared to that from rivers, where a complex of additional sampling methods should be applied to identify the fauna comprehensively (Son et al., 2013). Regard should be also paid for the cited study, where re-sampling was not applied due to the large number 
of samples: the accumulation curves were plotted chronologically as the samples were taken and were approximated by a power function that have not overcome the limit.

A total of six families of invertebrates (Chironomidae, Ceratopogonidae, Tubificidae, Naididae, Coenagrionidae, and Leptoceridae) should be considered as the richest in species number, comprising together $55 \%$ of the fauna diversity. As a rule, the number of dominant families is $10-15$ in comparative floristics (Tolmachev, 1974). In order to clarify the patterns influencing the formation of specific fauna of macrozoobenthos in different types of water bodies in various regions, further studies of its rank structure are required. The accumulation of such data should contribute to the development of comparative faunistics in general and comparative faunistics of macrozoobenthos in particular.

The positive relationship of the abundance of predator Chaoborus flavicans with depth and negative correlation with water temperature and the concentration of dissolved oxygen may be explained by its preference to inhabit the profundal zone of lakes, where it makes daily vertical migrations (Gosselin and Hare, 2003; Pekcan-Hekim et al., 2006; Xie et al., 1998). The negative relationship of this species with oxygen concentration, which contradicts the data of Xie et al. (1998) may be explained by the fact that the samples have been collected during the daytime, when the larvae are less active and keep near the bottom, avoiding the predatory pressure of fish (Gosselin and Hare, 2003; Pekcan-Hekim et al., 2006). Since this species predates outside the studied communities (Kajak and Rybak, 1979; Smyly, 1980), it should be considered as non-feeding in these communities, although it cannot be excluded from them totally, since it serves as a food for other predators of macrozoobenthos (dragonfly larvae, etc.).

The chironomids prefer the littoral and water edge zone more than the "profundal" zone, which is supported by a positive correlation of their abundance with temperature and oxygen concentration and by a negative correlation with depth. Glossiphonidae depend highly on the dissolved oxygen concentration due to their cutaneous respiration. The absence of a dependence of active predatory larvae of Odonata, including Corduliidae, with the concentration of dissolved oxygen may be explained by the presence of rectal tracheal gills. The predatory larvae of Ceratopogonidae depend positively on the water temperature since greater amount of trophic resources develops in warm waters in species-rich and abundant communities of the water edge and littoral zones (Table 1). Probably, for the same reasons, detritus feeders and obligate predators depend negatively on the depth and positively on the water temperature. In addition, both obligate predators and sestono- detrivorous filter feeders depend positively on the concentration of dissolved oxygen.

The species abundance and biomass did not depend on particular year, lake, and biotope; this may be explained probably by the low species richness in the samples, both in certain biotopes and even grouped by the lakes. Only seven species out of 103 found were registered in ten or more samples out of 51 obtained.

The small number of reliable relationships between the abundance of particular taxonomic and trophic groups and the factors analyzed may indicate that both spatial and temporal distribution of taxa are related much to the availability of food resources and the diversity of microbiotopes. Both saprobiological analysis (Prokin, 2014) and data on the dynamics of the trophicity coefficient for zooplankton (Krylov, 2015; Krylov and Zhgareva, 2016) testify indirectly to the change in the trophicity of lakes during the study period and characterize the lakes as eutrophic or hypertrophic in different years at different sites, depending on the flood period and the degree of overgrowth with macrophytes.

An analysis of the mutual association of species evidences on particular groups occurring together in certain years and/or in certain lakes. Thus, it is quite indicative for identifying the faunistic features of communities and thus presenting them as a "portrait of the faunistic core," while the standard methods of analyzing the dependence of the abundance of certain species and groups on the year and/or lake factor(s) lead to ambiguous results (see above). This is natural, since the species exist in certain communities, they interact with each other; however, these interactions just remain unaccounted when using traditional statistical methods.

Comparing our results obtained for lakes with the data on the structure of coenotic complexes of alien species in the Middle and Lower Volga River (Kurina and Seleznev, 2019), carried out using a similar method, a smaller number of mutually associated species should be noted $(43.7 \%$ of the total number (45 species) versus $72 \%$ (28 species) in the Volga River basin). Meantime, a larger number of groups (eight versus two) are observed in the lakes with a smaller number of links of certain species within the group. The maximum number of links for one species (Chironomus cingulatus) is seven in the studied lakes, but 14 for Echinogammarus warpachowskyi (G.O. Sars, 1894) in the Volga River basin. This is explained by rigidly structured (well-connected) consortium communities of the $M$ (Möbius) type, forming by edificator species (mollusks of the genus Dreissena), studied by E.M. Kurina and D.G. Seleznev (Kurina and Seleznev, 2019). We studied less connected communities of the $P$ (Peterson) type, which have been formed without an edificator species participating (terminology: Protasov, 1989, 2011). 
Further studies of groups of mutually associated species in communities with different organization strategies in the gradient of the $P-M$ typology may be useful for the development of ideas about their sustainability and stability. The proposed index of the strength of connectivity of the species composition (Cs) should contribute to improving the quality of the analysis of the data obtained, primarily when comparing $P$-and $M$-type communities.

Redundancy analysis allows us to state that environmental factors affect both the quantitative characteristics and species richness of communities (Fig. 4). At the same time, structural indices, which characterize the features of spatial distribution of the species abundance from the standpoint of dominance - equitability (evenness), do not depend on the analyzed factors (Fig. 4), as supported by correlation analysis. This distribution, which forms the structure of communities, is preconditioned by the interaction of species, by their direct and indirect biotic relationships within the community, and by both top-down and bottom-up control.

The study of the mutual association of species makes it possible to define the "faunistic cores of communities", which in our case characterize the macrozoobenthos of particular lakes and/or study periods.

\section{Funding}

The work was carried out within the Ministry of Science and Higher Education of the Russian Federation State Research Project no. AAAA-A18-118012690106-7 in the Joint Laboratory of Hydrobiological Monitoring of Water Bodies in the Middle Don Basin of the Papanin Institute of Biology of Inland Waters RAS and the Voronezh State University.

\section{Acknowledgments}

The authors are sincerely grateful to N.A. Karpov, E.V. Pechenyuk, and A.V. Krylov for their help during the study and valuable advice during preparing the article. Special thanks go to anonymous reviewers for valuable comments that help to improve the article.

\section{ORCID}

Alexander A. Prokin (iD 0000-0002-9345-5607 Dmitry G. Seleznev (D) 0000-0003-2782-1696

Alexander I. Tsvetkov (ID 0000-0002-0307-9864

\section{Supplementary data}

https://doi.org/10.23859/estr-210306

\section{References}

Arabina, I.P., Savitskiy, B.P., Rydnyy, S.A., 1988. Bentos meliorativnykh kanalov Poles'ya [Benthos of melioration canals in Poles'ye]. Uradzhay, Minsk, USSR, 40 p. (In Russian).
Davydenko, V.V., Biryukov, V.I., 2014. Osobennosti gidrologii poverkhnostnykh i gruntovykh vod $v$ Khoperskom zapovednike [Peculiarities of surface and ground waters hydrology in the Khopyor Reserve]. Trudy Khoperskogo gosudarstvennogo zapovednika [Proceedings of the Khopyor State Reserve] 9, 83-112. (In Russian).

Blondel, V.D., Guillaume, J-L., Lambiotte, R., Lefebvre, E., 2008. Fast unfolding of communities in large network. Journal of Statistical Mechanics, stacks.iop.org/JSTAT/2008/P10008. https://doi. org/10.1088/1742-5468/2008/10/P10008

Egunova, O.E., Kharchenko, N.N., 2020. Osobennosti gidrologicheskogo rezhima poimennykh ozer Khoperskogo zapovednika [Peculiarities of the hydrological rezhime of floodplain lakes in the Khopyor Reserve]. Sbornik statey VII Vserossiyskoi (nacionalnoy) nauchno-praticheskoi konferencii "Ustoichivoye razvitie prirodnykh territoryi osobo okhranyaemykh territoryi" [ Collection of Articles of the VII All-Russian (National) ScientificPractical Conference "Sustainable Development of Protected Areas"]. Natural ornithological park in the Imeretinskaya lowland, Sochi, Russia, 145154. (In Russian).

Erwin, K.L., 2009. Wetlands and global climate change: the role of wetland restoration in a changing world. Wetlands Ecology and Managements 17 (1), 71-84. https://doi.org/10.1007/s11273-008-9119-1

Gosselin, A., Hare, L., 2003. Burrowing behavior of Chaoborus flavivans larvae and its ecological significance. Journal of American Benthological Society 22 (4), 575-581. https://doi. org/10.2307/1468354

Griffith, D.M., Veech, J.A., Marsh, C.J. 2016. Probabilistic species co-occurrence analysis in $\mathrm{R}$. Journal of Statistical Software 69 (2), 1-17. https:// dx.doi.org/10.18637/jss.v069.c02

Gurevich, E.V., Markov M.L., 2017. Malovodyia na Evropeiskoi chasti Rossii [Low-waters in the European part of Russia]. Uchenyie zapiski RGGMU [Scientific notes of Russian State Hydrometeorological University] 49, 99-107. (In Russian).

Kabacoff, R.I., 2011. R in action. Data analysis and graphics with R. Manning Publications Co., Shelter, New York, USA, 472 p.

Kajak, Z., Rybak, J., 1979. The feeding of Chaoborus flavicans Meigen (Diptera, Chaoboridae) and 
its predation on lake zooplankton. International Review of Hydrobiology 64, 361-378. https://doi. org/10.1002/iroh.19790640310

Kendall, M. G., 1938. A new measure of rank correlation. Biometrika 30, 81-93. https://doi. org/10.1093/biomet/30.1-2.81

Krylov, A.V., 2015. Interannual changes in the summer zooplankton in the lakes of the Khopyor River flood plain. Biology Bulletin 42 (10), 891898. https://doi.org/10.1134/S1062359015100076

Krylov, A.V., Zhgareva, N.N., 2016. Vliyanie poyomnosti na letniy zooplankton malykh ozyor [Impact of period of flooding on summer zooplankton of small lakes]. Izvestiya RAN. Seriya geograficheskaya [Bulletin of Russian Academy of Sciences. Geographical Series] 1, 58-66. (In Russian).

Kurina, E.M., Seleznev, D.G., 2019. Analysis of the patterns of organization of species complexes of Ponto-Caspian and Ponto-Azovian macrozoobenthos in the middle and lower Volga reservoirs. Russian Journal of Ecology 50, 65-74. https://doi.org/10.1134/S1067413619010053

Monakov, A.V., 2003. Feeding of freshwater invertebrates. Kenobi Productions, Ghent, Belgium, $373 \mathrm{p}$.

Odum, E.P., 1969. The strategy of ecosystem development. Science 164 (3877), 262-270. https://doi.org/10.1126/science.164.3877.262

Pekcan-Hekim, Z., Liljendahl-Nurminen, A., Horppila, J., 2006. Chaoborus flavicans in the food web - competitor or resource for fish? Polish Journal of Ecology 54 (4), 701-707.

Pozdnyakov, A.A., 2005. O znachenii pravila Villisa dlya taksonomii [The importance of Willis' law for taxonomy]. Zhurnal obshchey biologii [Journal of General Biology] 66 (4), 326-335. (In Russian).

Prokin, A.A., 2014. Kolichestvennye i strukturnye kharakteristiki soobshchestv makrozoobentosa poymennykh ozer Khoperskogo zapovednika [Quantitative and structural characteristics of macrozoobenthos communities in floodplain lakes of the Khopyor Nature Reserve]. Trudy Khoperskogo gosudarstvennogo zapovednika [Proceedings of the Khopyor State Reserve] 9, 211-233. (In Russian).

Prokin, A.A., Reshetnikov, A.N., 2013. Fauna vodnykh makrobespozvonochnykh poymennykh ozer Khoperskogo zapovednika [Fauna of water macroinvertebrates of floodplain lakes in the Khopyor Reserve]. Trudy Khoperskogo gosudarstvennogo zapovednika [Proceedings of the Khopyor State Reserve] 8, 137-157. (In Russian).

Prokin, A.A., Seleznev, D.G., 2018. Interannual variations in species richness and quantinative parameters of macrozoobenthos in floodplain lakes of the Khoper Nature Reserve. Inland Water Biology 11 (1), 56-64. https://doi.org/10.1134/ S1995082918010121

Prokin, A.A., Seleznev, D.G., 2021, in press. Structure of the macrozoobenthos of small lakes under conditions of the flooding period changing. Inland Water Biology 5.

Protasov, A.A., 1989. Klassifikatsiya soobshestv presnovodnogo perifitona [Classification of communities of freshwater periphyton]. Gidrobiologicheskiy Zhurnal [Hydrobiological Journal] 25 (6), 3-9. (In Russian).

Protasov, A.A., 2011. Zhizn' v gidrosfere. Ocherki po obshchey gidrobiologii [Life in the Hydrosphere. Essays on General Hydrobiology]. Akademperiodika, Kiev, Ukraine, 704 p. (In Russian).

Ratkowsky, D.A., 1990. Handbook of nonlinear regression models. Marcel Dekker, New York, USA, $241 \mathrm{p}$.

Sheth, S.D., Padhye, A.D., Ghate, H.V., 2021. Effect of environmentonfunctional traits of co-occurringwater beetles. Annales de Limnologie 57 (2). https://doi.org/10.1051/limn/2020030

Shitikov, V.K., Zinchenko, T.D., Rozenberg, G.S., 2012. Makroekologiya rechnykh soobshchestv: kontseptsii, metody, modeli [Macroecology of river communities: concepts, methods, models.]. Kassandra, Tol'yatti, Russia, 255 p. (In Russian).

Silina, A.E., Prokin, A.A. 2008. The trophic structure of macrozoobenthos in marsh water bodies of the forest-steppe zone in the Middle Russian hills. Inland Water Biology 1 (3), 231-240.

Simpson, E.H., 1949. Measurement of diversity. Nature 163 (4148), 668. https://doi. org/10.1038/163688a0

Schoener, T.W., 1976. The species-area relation within archipelagos: models and evidence from island land birds. Proceedings of the $16^{\text {th }}$ 
International Ornithological Conference. Australian Academy of Sciences, Canberra, Australia, 629642.

Smyly, W.J., 1980. Food and feeding of aquatic larvae of the midge Chaoborus flavicans (Meigen) (Dipetra: Chaoboridae) in the laboratory. Hydrobiologia 70, 179-188. https://doi.org/10.1007/BF00015504

Son, M.O., Novitsky, R.A., Dyadichko, V.G., 2013. Recent state and mechanisms of invasions of exotic decapods in Ukranian rivers. Vestnik Zoologii 47 (1), 45-50. https://doi.org/10.2478/vzoo-2013-0004

Thomas, S.M., Bini, L.M., Bozelli, R.L., 2007. Floods increase similarity among aquatic habitats in river floodplain system. Hydrobiologia 579, 1-13. https://doi.org/10.1007/s10750-006-0285-y

Tockner, K., Florian, M., Ward, J.V., 2000. An extension of the flood pulse concept. Hydrological Processes 14, 2861-2883. https://doi.
org/10.1002/1099-1085(200011/12)14:16/17<2861::AIDHYP124>3.0.CO;2-F

Tockner, K., Stanford, J.A., 2002. Riverine flood plains: present state and future trends. Environmental Conservation 29, 308-330. https:// doi.org/10.1017/S037689290200022X

Tolmachev, A.I., 1974. Vvedenie v geografiyu rastenii [Introduction to plant geography]. Leningrad State University, Leningrad, USSR, 244 p. (In Russian).

von Foerster, H., 2003. Understanding understanding: essays on cybernetics and cognition. SpringerVerlag, New York - Berlin - Heidelberg, 362 p.

Xie, P., Iwakuma, T., Fujii, K., 1998. Studies on the biology of Chaoborus flavicans (Meigen) (Diptera: Chaoboridae) in a fish-free eutrophic pond, Japan. Hydrobiologia 368, 83-90. https://doi. org/10.1023/A:1003217325236 